\title{
Hvad taler vi om, når vi taler om Bernhard?
}

NIELSEN

c/o Bille, søndag 29. maj 2011

$(9: 27)$

Hvad taler Bernhard om, når han taler til og i os? Thomas Bernhard. Jeg skal tale om Thomas Bernhard. Hvad er Thomas Bernhard? Hvad taler vi om, når vi taler om Thomas Bernhard? 14 bogstaver, 14 tegn samlet i to grupper på en (oftest usynlig) linje. To ord. Thomas og Bernhard. Thomas Bernhard. Et navn. Et navn bestående af fornavn og efternavn eller Familienname. Thomas Bernhard er en singulær sproglig begivenhed. Der er kun én Thomas Bernhard, og det er denne enestående, eller enegående og i hvert fald altid enetalende Thomas Bernhard, vi taler om, når vi taler om Thomas Bernhard. Eller bare Bernhard. Aldrig bare Thomas. Enten Thomas Bernhard eller Bernhard. Når vi siger Thomas Bernhard, så ser vi et sort-hvid fotografi af et menneske for os. En mand. Det er
MIKKEL KRAUSE FRANTZEN

New York, onsdag 8. juni 2011

Hvad taler Bernhard selv om, når han taler? I og gennem sine bøger. Han taler om selvmord, altid selvmord, om forbrydelser og fortrædeligheder, og om Østrig, som ikke er gode gamle Østrig, men et forfærdeligt land. Bernhard taler om, hvor afskyeligt, ubærligt og uudholdeligt det er at bo dér (og hvor umuligt det er at flytte fra landet, fra stedet). U-stedeligt. Men hvordan tales der om disse emner? Der tales om det på anden hånd, tredje hånd, fjerde hånd. Det er altid: En siger noget, som indeholder noget, en anden har sagt, som så er en del af noget, en tredje har fortalt osv. Ligesom Bernhards alteregoer aldrig selv begår selvmord. Det er altid andre, den Anden, dobbeltgængeren, der begår selvmord. Fortællerne derimod er vidner, selvmordsvidner. Det er det, de taler om. Hvor kommer talen fra? Den kommer fra det tyske sprog, og det tyske sprog er nedrighedens sprog. Det tyske sprog kommer altid ne- 
Thomas Bernhard. Men når vi taler om Thomas Bernhard, så er det som oftest som afsender af den uafbrudte kæde af ord samlet $\mathrm{i}$ en bog eller flere sådanne kæder samlet i flere sådanne bøger. Det er ofte selve skriften, vi taler om, når vi taler om Thomas Bernhard. Den særligt bernhardske skrift, den særlige bernhardske ecriture, den særlige bernhardske skriftstemme. At læse den særlige bernhardske skrift er læsende at høre en stemme, der taler og taler og taler, fra bogen begynder, til den efter firs eller hundrede og firs eller trehundrede og firs sider, punktum, er slut. Tavshed. Men ikke stilhed. Ekkoet af stemmen fortsætter i os, kværnende, også efter vi har lukket bogen. Hvad taler den om, skriften? Hvad taler den om, skriftstemmen? Hvad taler Thomas Bernhard om, når han taler til os og i os? Det er et vigtigt spørgsmål, et spørgsmål, der kræver et svar. Måske dette: At læse Thomas Bernhard er at lade sig udsætte for et synsbedrag. I Bernhards bøger betyder ordene ikke det samme, som de betyder uden for bogen, uden for kæden af ord, uden for denne skriftstemmes kværnen i os. Thomas Bernhards bøger er til en vis grad skriftlige trompe l'œils. De bøger, som på forside og ryg bærer navnet Thomas Bernhard (som afsender), indeholder delvis lukkede tegnsystemer. Når skriftstemmen i bogen siger (i spontan dansk oversættelse og efter hukommelsen), "de østrigske restauranttoiletter er de mest uhumske i verden", eller "de østrigske politikere er alle katolsk-nationalsocialistiske", så betyder disse sætninger ikke det samme, som de ville gøre uden for bogen, i en $\varnothing$ strigsk avis, for eksempel. I en avis ville sådanne kategoriske udsagn eller defra, fra bunden (desuden føles tysk ikke godt i munden, det er skorpet og surt; i Auslöschung (1986) skriver Bernhard, at det tyske sprog er som bly, tungt som bly, langt fra guld). Sådan er det for Kafka og Robert Walser. Jakob von Gunten, von ganz unten. Det er dernedefra, at Bernhards skrift kommer. Sådan her karakteriserer Ingeborg Bachmann Thomas Bernhards stil: “...bei Bernhard ist alles zwanghaft, die Benutzung von furchtbar, dumm, geehrter Herr, Höflichkeiten, Distanzen, Vokabular des Erschreckens, eine Stigmatisierung, die Adjektive ehren wieder, die Verben sind von der größten Vielfältigkeit, die das Deutsche erlaubt, hinunterreden, nicht nur hineinreden, herausreden, überreden, zureden, bei Bernhard wird alles Hinunterreden, ein Hinabreden." Bernhards tale er en nedtalen. Nedefra taler den længere ned. Graver et hul. Indtil den ikke kan komme længere. Ned.

Men denne nedtalen er ikke det eneste, der karakteriserer Bernhards stemme. Vi er bestemt ude på noget, som vi kunne kalde for talens overdrev. En overdreven tale, en tale, der overdriver. Bernhard ville med sikkerhed skrive under på Hannah Arendts udsagn om, at det er tankens natur at overdrive. Og så er vi fremme ved de typiske sætninger om toiletterne og østrigske politikere. Det er Sandheder. Indlysende og tautologiske. Tit er det kursiverede sandheder. Tyskerne har en markant brug af formateret skrift, hvilket kan spores i Heideggers bindestregs-filosofi og altså også i Bernhards kursivprosa. Hvor englændere som regel ikke bruger andet end punktummer som stilistiske greb (korte hovedsætninger eksempelvis), så kræver den tyske syntaks noget andet; en anden brug af tegn og tegnsætning. Men tilbage til Sandheden. 
af en form for bevisførelse, eksempler, empiri. I den bernhardske skrift derimod, står sætningerne nøgne, uden nogen form for argumentation eller bevisførelse, de er ikke påstande eller personlige udsagn blandt mange andre mulige udsagn. De står der slet og ret uimodsigelige, for så vidt som de er uimodsagte. De er slet og ret Sandheden. Hvilket stemmen også ofte understreger: "Det er sandheden." Og sandheden eller sandhederne fremstår altid i deres radikalest tænkelige eller skrivelige form. De østrigske restauranttoiletter er aldrig blot blandt verdens mest uhumske, de er altid verdens absolut og uimodsigeligt og altså i sandhed mest uhumske toiletter. Das ist die Wahrheit. Disse absolutte og uimodsigelige sandheder begynder først for alvor at optræde eller slå igennem i Bernhards senere romaner, måske først efter Korrektur (1975). De absolutte sandheder og sproglige hyperboler bliver Thomas Bernhards gennembrud som skandaleforfatter i Østrig og det tyske sprogrum. De hyperbolende sandheder kan nemlig citeres, klippes ud af den bernhardske talestrøm og indsættes i en hvilken som helst avis. Og i en sådan avis betyder de pludselig noget helt andet, på én gang mere og meget mindre, end de gjorde i den bernhardske bog. "De østrigske politikere er alle katolsknationalsocialistiske," skriver og siger Thomas Bernhard. Skandale! I de første femten-tyve år, måske helt frem til midten eller sågar slutningen af 1970'erne, var de bernhardske romaner på en helt anden måde lukket om og i sig selv og den menneskelige eksistens. I sidste del af Verstörung (1967) bryder den senere
Foucault ville måske kalde Bernhards tale for: parrhesia. Sandhedssigen. Men også: Kritisk tale. Modig tale (er Bernhards tale virkelig dét?) Bernhards sandheder taler magten midt imod. Der er mere at sige om den sag. Der er også mere at sige om følelserne og humoren hos Bernhard. Han er en stor humorist. Scenen med de tjekkoslovakiske andenklassesvarer i romanen Gehen (1971) er Marx-brødrene værdig. Samtidig er Bernhard en bitch. Er det ikke rigtigt, at Thomas Bernhard er en kælling? Kan man kalde ham andet end Østrigs bitch? Han bitcher, han brokker sig, han klager i ét væk. Han er ikke så meget vred, som han er sur. Han er fyldt af ressentiment, og det er ikke nødvendigvis negativt. Vi kan måske endda gå så vidt som til at kalde det en dyd. Det er og var også medvirkende til, at Bernhard i den østrigske offentligheds øjne var sådan en skandale. Når alt det er sagt, kan man stadig sige mere. For eksempel kan man foreslå, at Bernhards skrift er en bil, der holder i tomgang. Wikipedia-definition af tomgang: det laveste omdrejningstal, en forbrændingsmotor roterer med, når den blot holder sig selv i gang uden at yde noget arbejde. I praksis vil det sige, at motoren går i tomgang, når speederen ikke aktiveres. Tomgangen er en hån mod bilens ydeevne (en række fælles EU-regler fastsætter grænser for "udstødningsgassens sammensætning målt ved tomgang") - her hos Bernhard en hån mod romanen som sådan. Der er noget lovovertrædende over denne talens tomgang, over den forurening, den forårsager. I Bernhards tekster synes (d)et (eneste) lyspunkt at være en pervers glæde ved at holde denne tomgang, denne skriftens motor i gang og forurene (samfundets og skriftens rum) så meget, som det er muligt. Det er afgørende at forstå, at der også er en form for nødvendighed over det: tomgangen sørger for, at 
så karakteristiske bernhardske skriftstemme pludselig igennem, og ikke som fortællerstemmen, ikke som Thomas Bernhards skriftstemme. Stemmen kommer udefra og brager og skærer sig invasivt ind i den bernhardske skrift. Romanens fortæller er en yngre mand, et berndhardsk alter ego. I sidste tredjedel af bogen når han frem til et slot og en vanvittig greve (eller noget lignende), som taler manisk og stort set fortrænger fortællerens egen stemme, som reduceres til den rolle som metastemme, som fortællerstemmerne efter Verstörung oftest selv tager sig af: "sagde fyrsten," "tænkte jeg siddende i øreklapstolen," "sagde jeg til mig selv, som jeg stod der i døren til restauranten, stadig ventende på værtinden.” Osv., osv. Den senere internationalt kanoniserede bernhardske skriftstemme kommer altså udefra, oppe fra bjergets top, langt ude i skoven, uden for byen, uden for den civiliserede verden, ude fra naturen, den allzumenschliche, alt for menneskelige natur: sammenbruddet, vanviddet, det forstyrrede, åndshovmodige, aristokratiske vanvid, som lige fra begyndelsen af forfatterskabet har truet både fortællerne (altid mænd og altid bernhardske alter egoer) og deres hovedpersoner. Og vanviddet, skriftstemmen vinder altid over romanernes hovedpersoner. Vanviddet og skriftstemmen vinder altid over mennesket, den ødelægger menneskene, den lader dem træde frem, idet den fortællende lader dem gå under. Romanernes hovedpersoner er altid Untergeher, undergængere. Men det er lige til det sidste, lige til den sidste roman Auslöschung (1986), Udslettelse, aldrig hverken de østrigske toiletter eller de katolsk- skriften (den gamle bil) ikke går i stå, om så selve skriftbevægelsen blot forløber og foregår på stedet. Man kunne indvende, at den evindelige vandring, den uophørlige gåen i Bernhards bøger modsiger eller underminerer tesen om talens tomgang. Men al den gåen skjuler kun det faktum, at nok er der bevægelse, men bevægelsen bevæger sig så at sige ikke, den går ikke noget sted, der gås ikke noget sted hen. Ofte viser bevægelsen sig at føre lige lukt tilbage til udgangspunktet, det, man troede var en bevægelse fra A til B, er en bevægelse fra A til A, ikke en linje, men en cirkel, en ring. Et sprint på stedet. En cirkelslutning (for tanken og vandringen). Alle bevægelser er tautologiske. Ligesom sandhederne og sætningerne er. Der er altså ingen reel bevægelse. Man kunne også spørge sig selv: er der nogen tid, nogen realtid eller nutid, hos Bernhard? Det er tvivlsomt. Selve tiden er andenhånds, ikke nærværende, dramatisk og direkte oplevet som sådan. Med andre ord: Nutiden - og måske endda også tiden som sådan - findes ikke i Bernhards bøger. Det er derfor, at der heller ikke findes det mindste spor af psykologisk realisme. Men hvad er det så? Hvordan skal man genrebestemme Bernhards bøger? Det er romaner, men er det ikke i lige så høj grad en komedie og/eller tragedie? "Ist es eine Komödie? Ist es eine Tragödie?”, hedder et af Bernhards prosastykker (her hedder det bl.a., at man bedst beskriver det, som man hader - men måske hader man også bedst det, som man beskriver, skriver om?) "Aber Sie dürfen es mir nicht sagen... Nein, sagen Sie es nicht," siger den mærkelige mand i dametøj på et tidspunkt i historien. Sig endelig ikke, om det er en tragedie eller komedie! Det forbliver et uafklaret spørgsmål: Tragedie eller komedie? 
i fortællingen ødelægger disse altid enestående enegående ensomme eksistenser. Det er stort set altid dem selv og deres eget livsprojekt og eksistensen an sich, der går under med dem, ofte med støtte fra de nærmeste, familien, stort set aldrig de bare lidt fjernere og aldrig de endnu fjernere østrigske politikere, til nøds blot med støtte fra den østrigske eller Niederösterreichische mentalitet eller folkesjæl. I næsten alle de bøger, der på deres forside har de to ord, de 14 tegn Thomas Bernhard som afsender, har hovedpersonen et livsprojekt, en besættelse, han er besat af forestillingen om det absolutte værk, altid et skrift, og næsten altid et filosofisk skrift som vil blive stående og få indflydelse på både filosofien og menneskelivene i eftertiden. Og altid, med stor konsekvens, $i$ hver eneste af Bernhards romaner, forbliver værket en forestilling, der materielt set og altså $i$ virkeligheden kun resulterer i en voksende og altid udskridende og komplet kaotisk dynge af fragmenter, notater på små sedler, et materielt kaos, som til sidst bliver så omfattende, så dyngendetyngende, at hovedpersonen går under, under det. Tilbage er skriften, skriftstemmen og dermed fortælleren, som fortæller sin hovedperson ned i mørket, lader ham forsvinde og står tilbage som det egentlige eller i hvert fald det eneste mulige værk: romanen.

Endvidere: Hvorfor den bernhardske skriftstemme ikke er en motor i tomgang, men tværtimod en kværnende fremadskriden, en gang, en vandring, som flere steder endda slår igennem som menneskelig figur $i$ selve fortæl-
Sikkert er det, at menneskene i Bernhards bøger altid fattes luft. Det er umuligt at trække vejret, luften er altid kvælende. Der er ingen frisk luft, men i modsætning til eksempelvis Racines Phaedra, hvor der ifølge Roland Barthes kun er sol og ingen skygge at gemme sig $i$, er der ingen sol hos Bernhard, men udelukkende dunkle skygger, indelukkede, mørke rum. En motor i tomgang. I en sur garage.

\section{København, primo august 2013}

Man kunne også spørge: Hvad griner vi af, når vi taler om og tænker på og simpelthen bare læser Thomas Bernhard? Der er uden en tvivl en latter, men hvilke(n) form(er) for latter? En af de ohne zweifel største humorister i det 20. århundrede, Samuel Beckett, skelner i Watt mellem tre former for latter: mellem en bitter, etisk latter (der ler af det, der ikke er godt), en hul, intellektuel latter (der ler af det, der ikke er sandt) og så en glædesløs, trist latter (der ler af det menneske, der ikke er lykkeligt). Den sidste latter opfatter Beckett som den højeste poetiske latter, hvorfor han også kalder den en ren latter. "Nothing is funnier than unhappiness," skriver Beckett senere.

Hos Bernhard finder man både en bitter latter, en hul latter og en latter, der ler af latteren selv; en latter uden lyden af latter, kunne man også sige, en latterløs latter. I det hele taget står resonanserne mellem de to, Beckett og Bernhard, nærmest i kø. Blandingen af komik og tragik - og det faktum, at det komiske moment ofte er mere tragisk end det tragiske selv. I den forbindelse er det at græde og det at le også som oftest to sider af samme sag: I direkte forlængelse af den citerede passage i Watt formulerer Beckett det på den måde, at de forskellige former for latter kun er former for tuden (modes of ululation). Becketts latter er således - ligesom Bern- 
lingen: I Gehen (1971), hvor der uafbrudt gås og hvor Das Gehen an sich fremstår som den sandt menneskelige bevægelses-, tænke- og taleform, og $i$ Verstörung, hvor den bernhardske skriftstemme netop kommer til verden under en vandring, idet fortælleren og den vanvittige greve går og går og går. (At de bernhardske fortællere så på den anden side ofte er gået $i$ stå, $i$ indgangspartiet til en skrækkelig restaurant, eller siddende $i$ en øreklapstol, er selvfølgelig paradoksalt, men samtidig en pointe, en skæbnens ironi, som genererer skriftstemmens rasende vandring mod målet: Udslettelsen, Undergangen, som altid, altid, og altid i sidste ende, og altså ikke på stedet, men først for enden af den præcist romanlange skriftvandring, kommer).

Endvidere: om den fornemmelse af afsnit, af næsten lige lange skriftlige udbrud, der inde $i$ den tilsyneladende uophørlige skrift følger hinanden, med læsetiden melder sig, og som viser sig at have sin årsag: at Bernhard skrev de fleste af sine bøger i daglige afsnit eller udbrud og ofte inden for rammen af en enkelt side, der først blev skrevet oppe fra øverste venstre hjørne og ned mod det nederste højre, hvorefter siden, når den var fyldt af linjer, blev yderligere overfyldt af små eller større indskud, $i$ kiler, i margen, overstregninger og overskrivninger etc., indtil den i dagens Sidste Ende stod som et overophedet skriftkompressoraggregat, rasende fortvivlet vibrerende. hards - uadskillelig fra gråd, fra tårer, fra øjne i vand: "And the laugh that once was bitter? Eyewater, Mr. Watt, eyewater." Men Bernhards humor er ikke sort og absurd, den er på den ene side mere anfægtet og aggressiv end Becketts: Til grund for Bernhards humor ligger en langt større vrede, irritation, forbitrelse, hans tale og skrift er opkørt og ophidset, eksalteret og ekstatisk på en måde, som den ditto hos Beckett slet ikke er. Og på den anden side er der en mere depressiv grundtone hos Bernhard. Hans bøger er bitre og miserable, de handler om død og ulykke; sygdom, sindssyge, selvmord.

Måske skal man sige det på følgende måde: Den latter, der er at finde i Bernhards forfatterskab, er en helt igennem depressiv latter, der gør både afsender og modtager ilde tilpas. I den selvbiografiske Die Ursache (1975) skelnes der implicit mellem størstedelen af byens indbyggere, som er "fuldkommen indespærret i det maskineri der bearbejder deres daglige sløvsind," og så den depressive jeg-fortæller, der tidligt erfarer, "hvor forfærdeligt livet og eksistensen i det hele taget er, og hvor lidt denne eksistens er værd, ja i krigen intet som helst er værd." Her tales der også om "en ulykkelig natur i form af et totalt ulykkeligt menneske..." Uanset hvor meget en sådan sætning klinger af Pascal eller Schopenhauer, kan man konstatere, at den depressive person er en person, der er ude af stand til at tro på de løgne, som et lykkeligt liv har som sin uundgåelige og nødvendige forudsætning. På den måde er målet for den depressive forfatter ikke at frembringe følelser af absurditet eller fremmedhed, men i første omgang at få læseren til at se tingene, som de virkelig er og (som om det i sig selv ikke var nok) dermed, 
c/o Bille, torsdag 9. juni 2011

Nej:

Bernhard taler ikke udefra, men inde fra samfundets spids, han er spidsborgerlighedens utilpassede og utilpasse stemme. Han brokker sig, men han gør det indefra, han er ikke gået, ikke blevet smidt ud, han er stadig del af det gode selskab, selv om han sidder i forværelset, han er ikke engang henvist til en pindestol på et kammer, nej, han sidder mageligt i en øreklapstol og brokker sig over og sviner alle de andre til, som opholder sig derinde i spidsborgerlighedens wienerstuer, i spidsborgerlighedens traditionsrige og "ægte" wienercaféer på Wiens dyreste og mest turistoverrendte hovedstrøg, som han og hans alter-egoer og deres selvmyrdede dobbeltgængere og undergængere er stamgæst(er) i og stamgænger(e) på. Han taler ikke magten imod, han brokker sig bare over etaten, kultureliten, tidens tilfældige magthavere, der alle kommer fra og er del af den samme spidsborgerlige overklasse som ham selv.

Og atter Nej:

Skriften i Bernhards bøger er ikke en tomgang, Bernhard og skriften vil altid et sted hen, Bernhard og hans skrift er god gammeldags ædelmodig højmodernisme, eksistentialisme, den har et ærinde, den vil sige noget om la condition humaine, den vil ind til en kerne, den borer sig ned, på stedet, ja, men hele tiden og i pludselige gennembrud dybere ned, den er alt andet end tom gang. i anden omgang, få ham eller hende til at få det meget værre, end han eller hun allerede har det.

Det er ét grundlæggende spørgsmål, man altid bør stille til Bernhards jeg-personer: Hvorfor tager du ikke bare livet af dig selv? I Der Keller (1976), opfølgeren til Die Ursache, beskrives det, hvordan den yngre, skoletrætte Bernhard havde valget mellem at holde op med at være og være imod alt, mellem at begå selvmord og forlade gymnasiet. Sådan er det hos Bernhard, der er altid et valg, og selvmordet er altid den ene mulighed i et hvilket som helst alternativ, den bernhardske fortæller står overfor og konfronteres med.

Sådan her sættes det på spidsen i Wittgensteins Neffe (1982): "Undertiden tænkte jeg: hvorfor vil jeg udsætte min død, hvorfor føjer jeg mig ikke ligesom alle andre? Hvorfor disse anstrengelser for at holde sig vågen, for ikke at dø, hvorfor?" Og i Die Ursache skriver Bernhard om sit violinspillende og kostskoleindespærrede selv, at det, der optager ham, er tanken om selvmord; at han plages af selvmordstanker, hver eneste gang han øver violin i et såkaldt skorum!: "At dræbe livet eller eksistensen for ikke mere at skulle leve og eksistere det, pludselig at gøre en ende på denne totale ynkelighed og hjælpeløshed ved at hoppe ud ad vinduet eller ved for eksempel at hænge sig i skorummet i stueetagen, forekommer ham at være det eneste rigtige, men han gør det ikke."

Men hverken jegpersonen i Der Keller, eller Wittgensteins Neffe eller Die Ursache eller nogen anden Bernhard-bog begår selvmord - selvom forholdene $\mathrm{i}$ Salzburg i sidstnævnte var sådan at "alt uafbrudt [havde] været en grund til at begå selvmord," og "den eneste flugtvej var selvmordet," så bliver det ved snakken. Tanken omsættes aldrig i handling. Og det er jo typisk for en depressiv anlagt 
Og javist:

Tautologisk er sandsigeriet, påstandene, skriftens overfladiske bevægelser, men i "det lange" løb indeholder hver roman et gennembrud, en kadence, ind $\mathrm{i}$ en stor, nærmest kærlig menneskelighed, en $\varnothing$ mhed, en stor, dyb sorg, som det tager adskillige (hundrede siders) tomgange på det sproglige stadion at slide sig ned til, som Joakim von And, der i sin rundgang på stedet også altid sled sig ned i en selvskabt cirkulær afgrund, en skyttegrav, Onkel Joakim såvel som Bernhard gravede hver deres skyttegrav og gik selv under i dem, men på meget menneskelig, ja, alzumenschlich vis.

$*$

c/o Sorø Akademi, mandag 26. august 2013

Så hvad er det, vi i sidste ende og i bratte hundrede og firs graders omvendinger undervejs græder over eller i hvert fald pludselig og uventet røres af, når vi læser Bernhard? Hvad er det, der gør, at latteren i sidste ende og undervejs brat forstummer og afløses af en eksistentiel smerte, ja, nogle gange ligefrem en sorg, som vi modsat latteren ikke bare kan lade runge ud og lægge bag os, men må bære med os videre på vejen tilbage i dagligsproget og livet uden for Bernhards skriftstemmeverden?

Det er det paradoksale, som ikke bare er en formel begivenhed i de bernhardske skriftstrømme, men en mimetisk genskabelse af det paradoksale i menneskene og i menneskelivet: at det værste også er det mest person. Som Freud forstod, så er der en intim forbindelse mellem depression eller melankoli og sandhed; der er noget sandt $i$ alt, hvad der kommer ud af melankolikerens mund (man kan kun undre sig over, hvorfor et menneske er nødt til at blive syg for at få adgang til en sådan sandhed, skriver Freud videre, men påpeger samtidig, at selvom melankolikere måske nok siger sandheden, så kan man ikke lade være med efterfølgende at spørge dem eller sig selv: og hvad så?) Den depressive person er altså én, der ved for meget, der har set sandheden for dybt i øjnene - og netop derfor er ude af stand til at handle. Det var også Hamlets problem ifølge Nietzsche, der i Tragediens Fødsel taler om en decideret Hamletlehre. Viden dræber handling, skriver han. Det må ikke misforstås, som at Hamlet ikke kan beslutte sig, at han står lammet midt i sine overvejelser. Det er ikke, fordi der er for mange muligheder, at man ikke handler. Det er, fordi man ved, fordi man har set sandheden. Og samtidig ved man, at det at handle ikke vil ændre noget som helst. Det er for Nietzsche ikke tvivlen, men visheden, der gør én gal. Sådan er det i Hamlet, og sådan synes det også at være hos Bernhard. Hans fortællere ved for meget, deres klarsyn blokerer for den ultimative handling, det at dræbe sig selv. Det værste inden for denne pessimistiske og depressive horisont - hvor alting altid kan blive værre endnu - er således ikke at $\mathrm{d} \varnothing$, men det ikke at $\mathrm{d} \varnothing$. Det er det fejlslagne eller nærmere det aldrig igangsatte selvmords tragikomik. Sandheden om samfundet leder udelukkende til en lede ved samfundet (og, natürlich, til litteratur).

Siger man depression og melankoli, siger man imidlertid også: mani. Som Simon Critchley og Jamieson Webster 
er dem, vi elsker, vores nærmeste, dem vi ikke kan holde ud og ikke kan undvære, og som vi med årene kender så ulideligt godt, at vi kan se, ned i mindste detalje, hvor latterlige, ynkelige, forfængelige, perverse, nedrige og mislykkede, men derfor også tragiske og rørende, de som mennesker, som ethvert menneske, er. Den menneskelige komedie, der langsomt folder sig ud gennem det bernhardske gesamtwerk, fra den kuldslåede Frost (1963) og den mørke forurettethed i ungdomsværkerne fra de tidlige tressere og den med årene stadig mere højlydte læserlatter i mødet med komedien, der kulminerer i 1980ernes boulevard- og Fußgängerzone-romaner og ophidselser, ville ikke have nogen klangbund uden den illusionsløse sorg, smerte og medlidenhed med menneskene, som altid i sidste ende får værkerne og læsningen af dem til at klinge ud i et dybt smilende-smerteligt suk. For Bernhards bøger er jo ikke bare skandaler og sprogspil, de er også dybt alvorlige eksistentialistiske opgør med og opgørelser over livet. Hvad ville ned-skrivningen af hr. Auersberger og Burgskuespilleren i Holzfällen (1984) være, hvis ikke begge de herrer, helt nede, på bunden, pludselig viste sig at være ikke blot rørende menneskelige, men også ligefrem livskloge, hvis de bare var et par idioter, som fortælleren, der er meget tæt på simpelthen at være Bernhards megafon, omkostningsfrit kunne rakke ned, men ikke også, samtidig og paradoksalt, en slags bernhardske lidelsesfæller og åndsfæller, der ikke blot at the end of the day, men for enden af livsbanen, i kadencen, er blevet lige skriver i en ny bog, Stay, Illusion! The Hamlet Doctrine (som der lånes fra her), så er manien den forvredne bagside af melankoliens möbiusbånd. En endeløs pendulering mellem mani og melankoli er Hamlet frem for alt og alle inkarnationen af. Men det er Bernhards fortællere også: Depressive, men manisk talende. Og måske er det på tide at opfatte og udnævne Bernhard til Østrigs Hamlet. Hamlet hvis problem ikke kun er, at han ikke kan dræbe sin fars morder, Claudius, men at han ikke kan dræbe sig selv. Han drømmer ellers meget tidligt om, at hans alt alt for faste kød kunne smelte og forsvinde som dug for solen, om at selvmord ikke var en forbrydelse mod Gud.

Så til spørgsmålet om Bernhards bøger er komiske eller tragiske, depressive eller maniske, må man så ikke sige: bådeog? I Wittgensteins Neffe tales der om de evigt fejlslagne forsøg på at diagnosticere titelpersonen (og der kunne lige så godt være tale om jeg-fortælleren selv): "disse evigt forkerte diagnoser. Det ene øjeblik sagde de manisk, det næste øjeblik depressiv, og det var altid forkert."

Der er i øvrigt en dansk forfatter, der for nylig har skrevet: "Livet er forfærdeligt, men når man bagefter fortæller om det, så er det ofte ganske rørende og latterligt." I samme bog, der bærer titlen Mine møder med De Danske Forfattere, omtales også en forfatter, der ikke ved "noget bedre end at være et sted, han hadede at være, og så skrive om det, hvor forfærdeligt det var, det hele..." Det er ikke Bernhard, men det kunne lige så godt være Bernhard, der blev talt om her (og guderne skal vide, at forfatteren da også er optaget for ikke at sige inspireret af Bernhard!). Intet sted er det tydeligere end i Holzfällen (1984) 
så illusionsløse og vise som Bernhard selv, ja, hvis de ikke også var en slags selvportrætter?

Og hvad ville disse desillusionerede ældre mænd, der godt ved, at drukkenskaben, dekadencen og al den snak altsammen bare er udflugter, udsættelser, at det eneste konsekvente ville være selvmordet, hvad ville de være uden de selvmyrdede, der på paradoksal vis holder dem i live? Burgskuespilleren har sin selvmyrdede kollega, Auersberger og fortælleren har deres selvmyrdede Joanna, og stort set alle de øvrige Bernhard-fortællere har hver deres selvmyrdede hovedperson, det er på paradoksal vis selvmorderne, deres tragedie og konsekvens, der holder de andre i live, får dem til hver dag alligevel, trods alt, at stå op og gøre det, de godt ved, er meningsløst: gå på scenen, skrive, spille klaver, drikke, opsøge eller lade sig lokke af det menneskelige selskab, de hader og ikke kan leve uden, og midt i alt dette forhadte menneskeliv, dette menneskemylder, at tale, fortælle og blive ved med at kværne.

Og når det kommer til stykket, er de bernhardske fortællere de eneste frelste og dermed også de største hyklere: Modsat alle de andre har de en mening med livet: Når Bernhards fortællere i modsætning til hovedpersonerne og en del af bipersonerne og Hamlet aldrig begår selvmord eller dør, så er det, fordi, de har en opgave, de kan ikke dø, de kan til nøds forstumme, men først, når de har fuldendt deres fortælling, når fortællingens musik er klinget ud. Så holder de kæft. Men de dør ikke. Aldrig. Ikke hvad vi ved af. (som måske er Bernhards mest komiske og rørende værk), hvor jeg-fortælleren sidder til et middagsselskab og bander langt væk over, at han er taget til det selv samme middagsselskab. Et såkaldt kunstnerisk middagsselskab vrænger han igen og igen, mens han sidder i en øreklapstol og i en indre monolog sviner de andre gæster til én efter én, gæster, som han af gode grunde ikke har set i godt 25 år.

Komikken i denne fortælling er, som altid, primært forankret i Bernhards stilistik. I den måde, han gentager ord på, kursiverer ord på, sammensætter ord på (og ofte kombineres de tre i form af en gentagelse af en neologisme i kursiv). Gentagelsen af "tænkte jeg i øreklapstolen" (han sidder som sagt i en øreklapstol og gør igen og igen opmærksom på, at han sidder i en øreklapstol. Over hundrede gange på under hundrede sider. Helt unødvendigt). Kursiveringen af vendingen kunstnerisk middag. Neologismen "generalfeltmarskalsbukser" (eller som i Gehen, "tjekkoslovakiske andenklassesvarer"), som Bernhard uden tvivl har udvalgt med forkærlighed og fornøjelse.

Andre komiske komponenter? To ting. For det første den uhyrlige persontegning (her må man ikke glemme bogens selvbiografiske forlæg, at de fiktive personer i bogen i vid udstrækning er og var virkelige personer i den dengang virkelige virkelighed), dvs. den nådesløshed, hvormed personer udleveres, hvormed de personlige udgydelser udgydes: Og for det andet den selvfølgelighed og uimodsigelighed, hvormed Sandheden siges. Holzfällen er udtryk for en aftens ophidselse (dette er bogens undertitel: en ophidselse), men den ophidsede persontegning drages aldrig $\mathrm{i}$ tvivl, sådan er det bare, Østrig, sådan er 
Så nej, nej og atter nej: Bernhards skrift er hverken bare en motor i tomgang eller en talen ned, nej, nej, nej, det passer ikke, at "bei Bernhard wird alles Hinunterreden, ein Hinabreden." Alle cirkelbevægelserne, alle tautologierne er del af skriftens overordnede eksistentielle og ikke mindst musikalske bevægelse, der altid fortsætter lige til enden, der med årene bliver stadig mindre bitter og forurettet og stadig mere melankolsk og forsonende. Og alt det, der undervejs i bevægelsen bliver talt ned, bliver samtidig ophøjet i det uforglemmelige, det uundværlige: De mennesker, vi ikke kan undvære, de mennesker vi, trods alt, ikke ville have været (noget eller dem, vi blev og er) uden. Og über alles: Østrig, det Salzburg og det Wien og den hjemstavn, hverken fortællerne eller Bernhard ville kunne leve eller skrive uden. Bernhard, såvel som hans fortællere og de skæbner, de fortæller, vil altid væk, og de fleste kommer også væk, men kun for - i sidste ende - at kunne vende tilbage. Og uanset hvor de end er derude $\mathrm{i}$ den større og altid bedre verden, så er der aldrig noget at skrive (hjem) om, hverken i det højstpriste Rom, London, Madrid, Venedig, norden eller syden. Kun i Østrig er der mennesker, steder og toiletforhold, der er værd at skrive om, og huse, det er værd at hænge sig i. Og hvad Bernhard selv angår: Uden Østrig, Wien, Burgtheater og hele den spidsborgerlige dannelseskultur ville han ikke have nogen at skrive for og ingen mulighed for skandale og dermed øjeblikkelig succes. Uden for Østrig, i Danmark og Tyskland und sonstwo synes vi jo alle sammen de bare, personerne: forfærdelige, afskyelige. Denne idiosynkratiske attitude kunne man kalde en aksiomatisk absolutisme. Det antages i fortællingen uden videre, at alt, hvad fortælleren siger er sandt (selvom det selvfølgelig ikke er sandt). Ophidselsen făr og har under alle omstændigheder en næsten tautologisk karakter.

Og så er der fortælleren selv, den depressive hovedperson, der kun viser sig at være alt, alt for menneskelig og ganske rørende. Han sidder og fyrer lort af, og ved tilsyneladende ikke "noget bedre end at være et sted, han hadede at være, og så skrive om det, hvor forfærdeligt det var, det hele..." - men han er, i sidste ende, præcis ligesom de personer, han retter sin ophidselse imod. Da fortælleren endelig, ved middagsselskabets opbrud og fortællingens afslutning, åbner munden for at tage afsked med værten Fru Auersberger, er det udelukkende lort, han fyrer af, men en anden type lort, nemlig den samme slags lort som han har siddet i øreklapstolen og foragtet aftenen lang: Han lyver og siger, nej hvor var det hyggeligt, og vi må virkelig se at genoptage kontakten og en masse andet lort. Han ser udmærket selv hvor nedrigt og forløjet et menneske, han også er. Og så løber han ud i natten, mens han tænker, at han både elsker og hader Wien og menneskene i Wien, lidt ligesom Quentin i William Faulkners Absalom! Absalom! der udbryder: "I dont hate it! I dont hate it!", da han bliver spurgt, hvorfor han hader Syden så meget (og alle ved, at hans benægtelse netop rummer en komisk kerne af bekræftelse, at hans udsagn om, at han ikke hader Syden, netop også er en tilkendegivelse af, at han hader Syden) - men hos Bernhard er det med omvendt fortegn: han hader det, han hader det, men han hader det ikke kun; at han overhovedet har behov for at udtrykke dette had så eftertrykkeligt viser, at 
bare, at Bernhard er herlig, vi irriteres måske, men altid kun personligt, aldrig kollektivt, vi giver ham aldrig modstand. Når det kommer til stykket, er vi ligegyldige; for Bernhard, hans fortællere og hovedpersoner og selvmordere er der kun ét kvalificeret himmelsk helvede på jorden, og det er $\emptyset$ strig. han til en vis grad også elsker Wien og Østrig og ikke kan forlade byen, landet eller verden for good.

Så han løber. Og tænker: "at denne by, jeg løber gennem, hvor frygtelig jeg end synes den er og altid har syntes den var, alligevel er den bedste by for mig, at dette forhadte, af mig altid forhadte, Wien, pludselig igen alligevel var det det bedste, mit bedste Wien, og at disse mennesker, som jeg altid har hadet, og som jeg hader og altid vil hade, alligevel er de bedste mennesker, at jeg hader dem, men at de er rørende..." Sådan ser en komisk kovending ud.

Så han løber. Fordi han straks og med det samme må hjem og skrive noget om denne såkaldte kunstneriske middag, han løber gennem byen, gennem natten, hjem for at skrive, før det er for sent. Og det er denne uopsættelighed, man altid mærker, når man læser Bernhard. Og her forlader man endegyldigt fortællingen og på dette tidspunkt er det ikke længere muligt at skelne, hvem der ler, og hvem der ikke gør. Hvem, der griner af hvem. Hvem, der ler sidst og bedst (forfatteren? fortælleren? læseren?) Men en ting står et hundrede procent klart: Man må ikke misforstå denne latter som en forsonende latter, det er derimod og til den bitre ende en fredsforstyrrende og frostfuld latter. En latter, man ikke kan lune sig ved. Man ler og ler, og så pludselig ler man ikke mere. Og så forlader man alligevel ikke fortællingen uden en sidste latter over en fortæller, som er blevet afsløret som et menneske som alle andre, og som synes suspenderet i sit stormløb gennem Østrigs nat: På én gang på vej hen imod sin fortælling og samtidig $i$ fuldt firspring på vej væk fra sig selv og sit liv og måske frem for alt fra lyden af latter. Men det er umuligt: Hvis latteren er hans skygge, er han ikke Lucky Luke. 